\title{
Effects of Compounded soil with Feldspathic sandstone and Sand On Physical and Chemical Characters and Yield
}

\author{
$\mathrm{Ya} \mathrm{Hu}$ \\ 1Shaanxi Provincial Land Engineering Construction Group Co., Ltd, Xi'an, 710075, China; \\ ${ }^{2}$ Shaanxi Province Land Reclamation Engineering Technology Research Center, Xi'an, 710075, \\ China; \\ 3Key Laboratory of Degraded and Unused Land Consolidation Engineering, Ministry of Land and \\ Resources of China, Xi'an, 710075, China.
}

\begin{abstract}
Keywords: Feldspathic sandstone and Sand, Physical and Chemical Characters, Yield Abstract. In order to study the optimal ratio of compound suitable for crop growth ,analyzed physical and chemical Characters and crop yield of compounded soil with feldspathic sandstone and Sand (proportion: 1:1, 1:2,1:5) by plot test. The results showed that as the content of feldspathic sandstone decrease, the texture changes from sandy loam to loamy sand, water-holding ability is abate, 1:2 compound soil's density is small, big graded aggregation mass is high in the water stability aggregation, so the soil structure stability is strong. Different proportion of soil's average $\mathrm{pH}$ is 8.36, effective phosphorus content is high and the total nitrogen, available potassium and organic matter content is low in soil after one year plant ,1:2 compound soil is high and balanced nutrient content. The adaptability of different crops to compound soil is different, the yield was higher in 1:2 and 1:5.
\end{abstract}

\section{Introduction}

Feldspathic sandstone is widely distributed as one of the four major sandy areas in China[1]. No water is hard as stone, and the water is soft as mud. It is very easy to be weathered and eroded[2]. The wind sand soil has better water permeability $[3,4]$ but the water retention is poor, which is called "two evils". The new soil is formed by using the complementarity of the physical composition of the sand soil and the feldspathic sandstone. which is referred to as the "compound soil" is of great significance to reduce soil erosion and desertification.

In order to find the optimal compound proportion, analyzed the physical and chemical characters of the compound soil based on the previous research results in recent years. This paper provides a reference for further study on the technology of feldspathic sandstone and sand compounded, and promotes the promotion of the technology and the sustainable development of agriculture in the sand area.

\section{Materials and methods}

Study area. Test located in Chu yuan village, du village, fuping county, weinan city, Shaanxi province. Which belongs to the warm temperate and semihumid zone, average annual rainfall is $472.97[\mathrm{~mm}], 49$ percent is from July to September. The annual evapoproportion is $1000-1300$ [mm], Frostless Season is 225 days. Annual mean temperature is $13.40^{\circ} \mathrm{C}$, summer maximum temperature is $41.80^{\circ} \mathrm{C}$, winter minimum temperature is $-22^{\circ} \mathrm{C}$. Total annual light energy radiation is $518.6-535.0[\mathrm{~kJ}$ $\mathrm{cm}^{-2}$ ]. Climatic conditions can meet the needs of crop growth.

Test design. There were three treatments in the experiment, and the proportion of the mixed volume of the feldspathic sandstone and sand was 1:1, 1:2 and 1:5, each of them was treated with three repetitions. Total of 9 experimental plots and a single test area is $4\left[\mathrm{~m}^{2}\right] .30 \mathrm{~cm}$ above the surface is mixed of feldspathic sandstone and sand. And 30 70 cm layer of soil is completely filled with sand. The experimental feldspathic sandstone and sand were collected in xiaoji khan village, yuyang district, yulin. Crop varieties, irrigation and fertilization methods are managed according to local customs. 
Detection method. Determination of soil texture by Mastersizer 2000[5]. bulk density and saturated conductivity by ring knife method. The content of water stability aggregates was determined by Elliott wet sieve method. The field moisture, wilting coefficient, effective water holding and capillary porosity were obtained through the water characteristic curve. Determination of $\mathrm{pH}$ by glass electrode method, total salinity by gravimetric method, total nitrogen content by total nitrogen automatic discontinuous chemical analyzer, effective phosphorus content by anticolorimetric method of platinum antimony, potassium content by flame photometry, organic matter content by potassium dichromate capacity method.

Data processing. Using Microsoft excel and origin to deal with data.

\section{Results}

Physical Characters. Table 1 shown the soil quality and bulk density of the complex soil, and it can be seen from the table that the texture of the three kinds of complex soil is changed from sandy loam to sandy soil.

Table 1 Quality and bulk density of compound soil

\begin{tabular}{cccccc}
\hline Proportion & Sand[\%] & Silt[\%] & Clay[\%] & Quality & Bulk density $\left[{\left.\mathrm{g} . \mathrm{cm}^{-3}\right]}^{-3}\right.$ \\
\hline $1: 1$ & 68.46 & 24.02 & 7.52 & Sandy loam & 1.54 \\
$1: 2$ & 76.69 & 18.85 & 4.46 & Loamy Sand & 1.49 \\
$1: 5$ & 82.40 & 13.20 & 4.40 & Loamy Sand & 1.50 \\
\hline
\end{tabular}

The content of sand grains increased with the increase of sediment content, respectively $68.46 \%$, $76.69 \%$ and $82.4 \%$, and the content of powder and clay decreased with the increase of sediment content. In the proportion of 1:1, the powder grain content is up to $24.02 \%$ and the soil transpiration is large in the long time which has a weakened effect on soil water storage, water diversion and water retention, it is not conducive to the growth of crops. Density of 1:1 is larger than 1:2, Soil bulk density indicates the soil is porous and crop root growth and biomass accumulation were better.

Table 2 shows the moisture parameters of the complex soil. As can be seen from the table that there is a significant difference between the water holding capacity and retention capacity of the different proportion of feldspathic sandstone and sand. With the decrease of the proportion of feldspathic sandstone, the soil water holding capacity decreased, and the amount of field water, wilting coefficient and effective water holding decreased. Effective water holding change is the smallest of 1:5. It is suggested that adding a certain amount of feldspathic sandstone to the wind sand soil can increase the water holding capacity of the complex soil, and achieve the effect of drought in the dryland, thus providing the necessary moisture support for the normal growth of the crops.

Table 2 Water parameters of compound soil

\begin{tabular}{cccccc}
\hline Proportion & $\begin{array}{c}\text { Field capacity } \\
{[\%]}\end{array}$ & $\begin{array}{c}\text { Wilting } \\
\text { coefficient } \\
{[\%]}\end{array}$ & $\begin{array}{c}\text { Effective } \\
\text { water capacity } \\
{[\%]}\end{array}$ & $\begin{array}{c}\text { Satuproportion } \\
\text { conductivity } \\
{\left[\mathrm{mm}^{-1} \mathrm{~min}^{-1}\right]}\end{array}$ & $\begin{array}{c}\text { Capillary } \\
\text { porosity } \\
{[\%]}\end{array}$ \\
\hline $1: 1$ & 11.72 & 6.53 & 5.19 & 0.23 & 3.86 \\
$1: 2$ & 9.92 & 5.06 & 4.87 & 0.54 & 3.94 \\
$1: 5$ & 7.65 & 3.30 & 4.35 & 1.47 & 4.11 \\
\hline
\end{tabular}

Soil aggregate impact soil porosity, hold water, permeability and resistance to corrosion(Figure 1). through the wet sieve method to get the water stability of aggregate can reflect the evolution course of soil quality. Figure 1 shown the proportion of the feldspathic sandstone and sand has obvious influence on the soil water stability aggregates. The soil aggregate structure was the aggregate of $>0.25 \mathrm{~mm}$ granule, and its quantity was positively correlated with soil fertility. The aggregates of $>0.25 \mathrm{~mm}$ in the mixture of $1: 1,1: 2$ and $1: 5$ were respectively $20.5 \%, 33.3 \%$ and $32.1 \%$ respectively. The agglome proportion of $>0.25 \mathrm{~mm}$ is mainly concentrated in $0.25 \sim 0.5 \mathrm{~mm}$ granule. The stronger the stability of soil structure with the higher the mass fraction of large aggregates in the 
compound soil. The distribution of the 1:2 composite soil's water stability mass fraction is better than the other two.

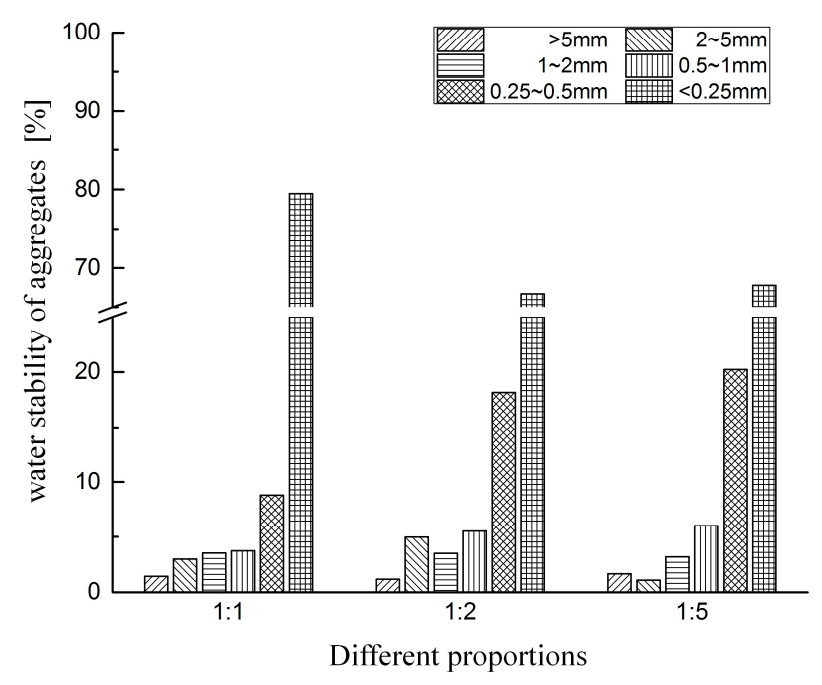

Figure 1 The distribution of soil water stability of aggregates in different proportions.

Chemical Characters. The nutrient content of arsenic sandstone and windblown sand itself is very low. The compound soil nutrient after one year of planting was measured (Table 3). Mean of pH of compound soils is 8.36. The total nitrogen content increased with the decrease of the content of feldspathic sandstone in the compound soil. Under the influence of the low nitrogen content of the feldspathic sandstone and sand, the nitrogen residue in the soil is very small even when nitrogen fertilizer is used during planting. So the content of total nitrogen in three types of compound soil is low in soil nutrient grading standard. The effective phosphorus content varies from high to low is 1:5、1:1、1:2 and be Level II in soil nutrient classification. The reason for the high phosphorus content may be there are few phosphorus fixing factors in the compound soil. For phosphorus fertilizer is easy to absorb and fix, it remains in the soil as effective phosphorus, except for being absorbed and used by crops. Distribution of soil available $\mathrm{k}$ content in the highest is 1:1, the lowest is 1:2,All compound soils' available potassium content in soil nutrient classification standard is very low. This may be due to the soil non-loess parent material used in the compound soil, the soil itself has little potassium content and a large amount of potassium is absorbed by the crops. Organic matter content of compound soil of 1:2 is highest and 1:1 is lowest. The results showed that the plant residues and root exudates were more in the soil after the growth of the soil, which had a positive effect on the storage of soil nutrients.

Table 3 Compound soil nutrient content.

\begin{tabular}{|c|c|c|c|c|c|c|}
\hline Proportion & $\mathrm{pH}$ & $\begin{array}{c}\text { Total salt } \\
{\left[\mathrm{g} \cdot \mathrm{Kg}^{-1}\right]}\end{array}$ & $\begin{array}{c}\text { Total } \\
\text { nitrogen } \\
{\left[\mathrm{g} . \mathrm{Kg}^{-1}\right]}\end{array}$ & $\begin{array}{l}\text { Effective } \\
\text { phosphorus } \\
{\left[\mathrm{mg} \mathrm{Kg}^{-1}\right]}\end{array}$ & $\begin{array}{c}\text { Available k } \\
{\left[\mathrm{mg} \cdot \mathrm{Kg}^{-1}\right]}\end{array}$ & $\begin{array}{c}\text { Organic } \\
\text { matter } \\
{\left[\mathrm{g} \cdot \mathrm{Kg}^{-1}\right]}\end{array}$ \\
\hline $1: 1$ & 8.37 & 0.54 & 3.33 & 30.75 & 10.71 & 2.50 \\
\hline $1: 2$ & 8.32 & 0.53 & 3.78 & 28.91 & 7.30 & 2.98 \\
\hline $1: 5$ & 8.40 & 0.69 & 3.98 & 34.42 & 8.74 & 2.85 \\
\hline
\end{tabular}

Comprehensive soil nutrient content, nutrient of compound soil of 1:2 is high and balanced, compound soil of 1:5 is second and compound soil of 1:1 is poor.

Yield. When planted corn, wheat and soybean, the yield was the highest in 1:2 and the lowest in $1: 1$, that is corn, wheat and soybeans were more suitable to be cultivated on the compound soil of 1:2 (Figure 2). When planted kartoffel, the yield was the highest in $1: 5$ and the lowest in $1: 1$, that is kartoffel was more suitable to be cultivated on the compound soil of 1:5. It indicated that crop yield is obviously influenced by crop type and not significantly influenced by compound proportions. Overall, 
the yield was higher in 1:2 and 1:5, the lower in 1:1. The adaptability of different crops to soil is different, so it is not possible to evaluate which compound soil has the best proportion according to the yield of a particular crop.

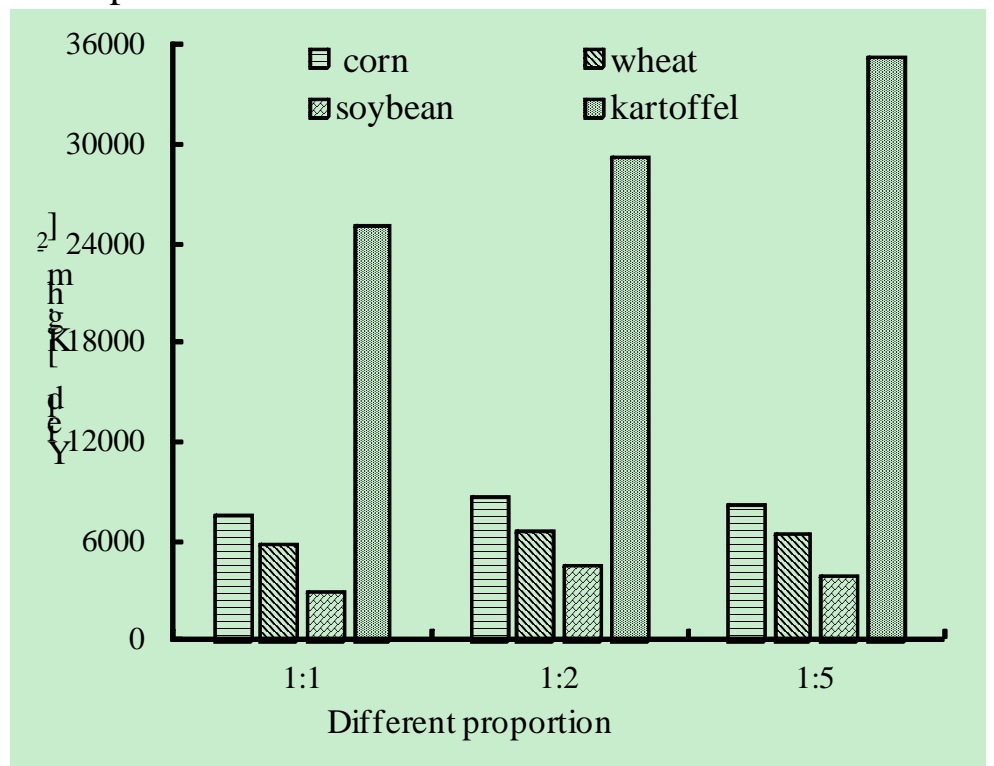

Figure 2 The Yield of different proportions

\section{Conclusions}

(1) With the decrease of the content of arsenical sandstone, the texture is changed from sandy loam to sandy soil. Bulk density of compound soil of 1:2 is small and the soil is porous and porous. With the decrease of the proportion of arsenicals, the water-holding capacity of the complex soil is weakened, and the addition of a certain amount of arsenicalsand in the wind sand soil can increase the water holding capacity. The mass fraction of large aggregates in water stability aggregates of compound soil of 1:2 is large. Its soil structure has strong stability.

(2) The effective phosphorus content in soil was high, the content of total nitrogen, instant potassium and organic matter was low after a year of planting, nutrient of compound soil of 1:2 is high and balanced, compound soil of 1:5 is second and compound soil of 1:1 is poor.

(3) The adaptability of different crops to compound soil is different, the yield was higher in 1:2 and $1: 5$, the lower in $1: 1$.

\section{Acknowledgments}

This work was supported by the the Scientific Research Item of Shaanxi Provincial Land Engineering Construction Group (DJNY2018-23、DJNY-2018-24).

\section{References}

[1] Zhang W, Han J, Wang H, et al. The improvement effects of softrock on sandy soil in Mu Us sandy land[J]. Journal of Arid Land Resources \& Environment, 2015.

[2] Wang $\mathrm{Y}, \mathrm{Wu} \mathrm{Y}$, Kou Q, et al. Definition of arsenic rock zone borderline and its classification[J]. Science of Soil \& Water Conservation, 2007, 5(1):14-18.

[3] Wang H Y, Han J C, Luo L T, et al. Regulatory Role of Sand in Soil Formation from Soft Rock and Sand[J]. Chinese Journal of Soil Science, 2014.

[4] Han J, Liu Y, Luo L. Research on the core technology of remixing soil by soft rock and sand in the Maowusu sand land region[J]. China Land Sciences, 2012.

[5] Zhang L, Han J, Wang H, et al. Grain size composition change after feldspathic sandstone and aeolian sandy soil compounding[J]. Sswcc, 2015. 